University of Rhode Island

DigitalCommons@URI

Open Access Master's Theses

2017

\title{
A Native Lepidopteran is Impacted by Host Defenses Induced by Hemlock Woolly Adelgid (Adelges tsugae)
}

Mary M. Mallinger

University of Rhode Island, marymallinger@uri.edu

Follow this and additional works at: https://digitalcommons.uri.edu/theses

\section{Recommended Citation}

Mallinger, Mary M., "A Native Lepidopteran is Impacted by Host Defenses Induced by Hemlock Woolly Adelgid (Adelges tsugae)" (2017). Open Access Master's Theses. Paper 1034.

https://digitalcommons.uri.edu/theses/1034

This Thesis is brought to you for free and open access by DigitalCommons@URI. It has been accepted for inclusion in Open Access Master's Theses by an authorized administrator of DigitalCommons@URI. For more information, please contact digitalcommons-group@uri.edu. 


\begin{abstract}
A NATIVE LEPIDOPTERAN IS IMPACTED BY HOST DEFENSES INDUCED BY HEMLOCK WOOLLY ADELGID (ADELGES TSUGAE)

BY

MARY M. MALLINGER

A THESIS SUBMITTED IN PARTIAL FULFILLMENT OF THE

REQUIREMENTS FOR THE DEGREE OF

MASTER OF SCIENCE

IN

BIOLOGICAL AND ENVIRONMENTAL SCIENCES
\end{abstract}

UNIVERSITY OF RHODE ISLAND

2017 
MASTER OF SCIENCE THESIS

$\mathrm{OF}$

MARY M. MALLINGER

APPROVED:

THESIS COMMITTEE:

MAJOR PROFESSOR: $\quad$ EVAN L. PREISSER

CO-MAJOR PROFESSOR: CAROL S. THORNBER

RICHARD A. CASAGRANDE

COLIN M. ORIANS

DEAN OF THE GRADUATE SCHOOL: NASSER H. ZAWIA

UNIVERSITY OF RHODE ISLAND

2017 


\begin{abstract}
Eastern hemlock, Tsuga canadensis, is currently experiencing widespread mortality due to the invasive hemlock woolly adelgid (HWA; Adelges tsugae). Eastern hemlock looper (Lambdina fiscellaria), another hemlock pest, is a native lepidopteran that has reached outbreak levels in the past. While these insects share a host and overlap in range, little is known about their interactions. Research has shown that HWA infestation increases methyl salicylate concentrations (an indicator of the induction of the salicylic acid pathway) in hemlock tissue while hemlock looper, a chewing insect, likely elicits the jasmonic acid pathway. While plants are capable of inducing both of these defensive pathways, they have been found to be mutually antagonistic. We tested the hypothesis that looper performance is affected by prior HWA infestation and plant defense. Specifically, we hypothesized that looper larvae would perform better on HWA infested hemlock foliage. Looper were reared to pupation on hemlock foliage that was either infested or uninfested with HWA. Within those treatments, groups of foliage were sprayed with defensive elicitors to induce either the jasmonic- or salicylic-acid pathway. We also analyzed total phenolic content and terpenoid levels in host needle tissue in all treatments. Application of the chemical elicitors negatively affected looper survival, and their impact was altered by HWA presence. Larval survival was significantly lower in treatments where both HWA and elicitor were present. In contrast, larval survival was higher in the HWA-infested control treatment in comparison to the uninfested treatment. This demonstrates a strong interactive effect between HWA and elicitor. The combined effect of elicitor and HWA infestation led to increases in both phenolics and terpenoids, suggesting a major role for these compounds in plant defense. This study demonstrates
\end{abstract}


the complex host-mediated interactions occurring between a native and an invasive insect which may aid in the further study of insect interactions. 


\section{ACKNOWLEDGEMENTS}

First and foremost, I would like to thank Dr. Evan Preisser, my major professor, for his continuous support and guidance throughout my time at the University of Rhode Island. I would also like to thank my committee members, Dr. Carol Thornber, Dr. Richard Casagrande, and Dr. Colin Orians, for contributing so much to the design and analysis of this project. Thanks to Dr. Larry Englander for chairing the committee and always expressing genuine interest. I am grateful to Drs. Chad Rigsby and Robert Schaeffer for putting in countless hours in the laboratory and answering my many questions regarding plant chemistry. Emma Shoemaker and Alex Baranowski, thank you both for being so actively involved throughout the project. Lisa Tewksbury, your assistance in the Biological Control Lab was truly invaluable. And a huge thanks to Claire Wilson, Elizabeth Whitney, and Katharine Harrison for not only supporting me intellectually, but for constantly brightening the office as well as my mood. A special thanks to my husband Paul McDivitt for sitting through many practice talks and actively delving into the world of the hemlock woolly adelgid with me. This project would not have been possible without funding from the National Science Foundation, as well as support from the University of Rhode Island through graduate teaching assistantships. 


\section{PREFACE}

The following thesis has been submitted in manuscript format following the formatting guidelines of the journal Ecology. 


\section{TABLE OF CONTENTS}

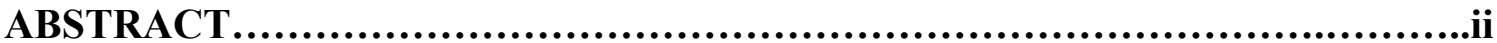

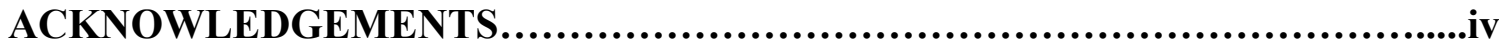

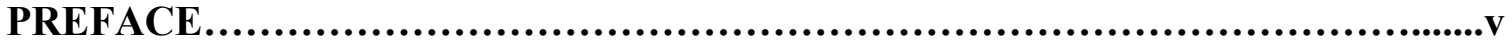

TABLE OF CONTENTS .............................................................

LIST OF TABLES......................................................................

LIST OF FIGURES................................................................

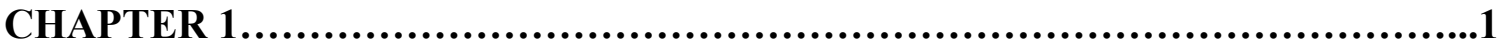

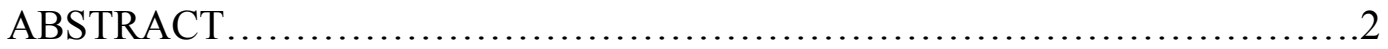

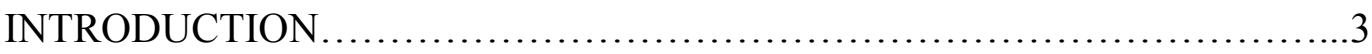

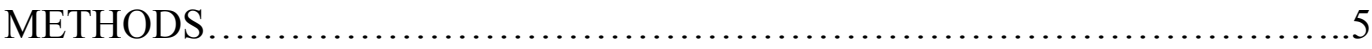

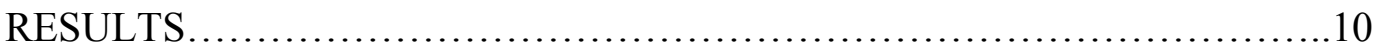

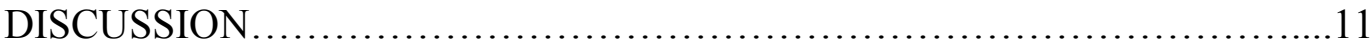

ACKNOWLEDGEMENTS..................................................14

LITERATURE CITED ................................................. 15

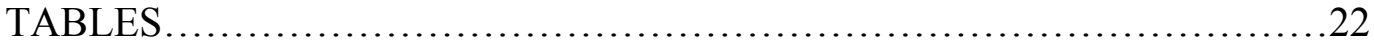

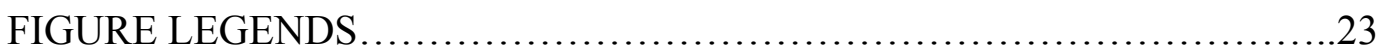

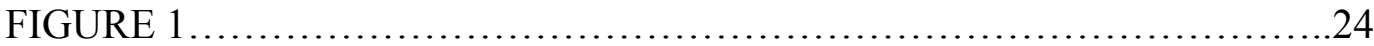

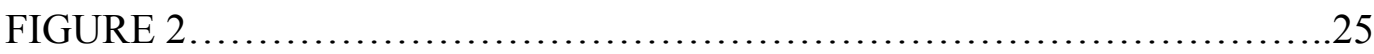

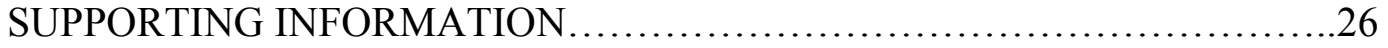




\section{LIST OF TABLES}

TABLE

PAGE

Table 1. HWA, elicitor, and interactive effects on response variables.................21 


\section{LIST OF FIGURES}

FIGURE

PAGE

Figure 1. Percent looper larval survival over time................................23

Figure 2. (A) Total phenolic content and (B) terpenoid levels of sampled needle tissue per

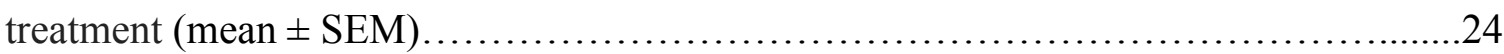




\section{CHAPTER 1}

A native lepidopteran is impacted by host defenses induced by hemlock woolly adelgid (Adelges tsugae)

\section{Authors}

Mary M. Mallinger ${ }^{1}$; Chad Rigsby ${ }^{2}$; Robert N. Schaeffer ${ }^{3}$; Colin M. Orians ${ }^{4}$; Carol S. Thornber $^{5}$; Evan L. Preisser ${ }^{6}$

Manuscript in preparation for Environmental Entomology

\footnotetext{
${ }^{1}$ University of Rhode Island, Kingston, RI; marymallinger@uri.edu

${ }^{2}$ University of Rhode Island, Kingston, RI; rigsby@uri.edu

${ }^{3}$ Washington State University, Pullman, WA; robert.schaeffer@wsu.edu

${ }^{4}$ Tufts University, Medford, MA; colin.orians@tufts.edu

${ }^{5}$ University of Rhode Island, Kingston, RI; thornber@uri.edu

${ }^{6}$ University of Rhode Island, Kingston, RI; preisser@uri.edu
} 


\begin{abstract}
Eastern hemlock, Tsuga canadensis, is currently experiencing widespread mortality due to the invasive hemlock woolly adelgid (HWA; Adelges tsugae). Eastern hemlock looper (Lambdina fiscellaria), another hemlock pest, is a native lepidopteran that has reached outbreak levels in the past. While these insects share a host and overlap in range, little is known about their interactions. Research has shown that HWA infestation increases methyl salicylate concentrations (an indicator of the induction of the salicylic acid pathway) in hemlock tissue while hemlock looper, a chewing insect, likely elicits the jasmonic acid pathway. While plants are capable of inducing both of these defensive pathways, they have been found to be mutually antagonistic. We tested the hypothesis that looper performance is affected by prior HWA infestation and plant defense.
\end{abstract} Specifically, we hypothesized that looper larvae would perform better on HWA infested hemlock foliage. Looper were reared to pupation on hemlock foliage that was either infested or uninfested with HWA. Within those treatments, groups of foliage were sprayed with defensive elicitors to induce either the jasmonic- or salicylic-acid pathway. We also analyzed total phenolic content and terpenoid levels in host needle tissue in all treatments. Application of the chemical elicitors negatively affected looper survival, and their impact was altered by HWA presence. Larval survival was significantly lower in treatments where both HWA and elicitor were present. In contrast, larval survival was higher in the HWA-infested control treatment in comparison to the uninfested treatment. This demonstrates a strong interactive effect between HWA and elicitor. The combined effect of elicitor and HWA infestation led to increases in both phenolics and terpenoids, suggesting a major role for these compounds in plant defense. This study demonstrates 
the complex host-mediated interactions occurring between a native and an invasive insect which may aid in the further study of insect interactions.

Keywords: hemlock woolly adelgid, hemlock looper, phenolics, terpenoids, Tsuga canadensis, plant defense, salicylic acid, jasmonic acid.

\section{INTRODUCTION}

Most long-lived plant species must withstand both simultaneous and sequential attacks from multiple herbivores. Interactions between herbivores that share a host can take several forms. Insects that feed at the same time can interact either directly (e.g., interference competition) or via their impact on the shared resource (e.g., exploitative competition) (Park 1948, Mattson 1986, Denno et al. 1995). For herbivores that differ in their phenology, these effects are necessarily asymmetric - feeding by an earlier-arriving insect species, for instance, may affect a later-arriving herbivore via changes in the host plant. Such herbivore-induced changes may negatively impact the later-arriving species by increasing plant defense or decreasing host quality (Faeth 1986, Harrison and Karban 1986); it is also possible, however, for the early-arriving species to benefit the laterarriving one via decreases in plant defense (Rodriguez-Saona et al. 2010, Soler et al. 2012).

The induced production of chemical compounds is a commonly-used defense against herbivory (Karban and Baldwin 1997). Two of the most well-studied plant defense pathways are the salicylic acid (SA) and jasmonic acid (JA) pathways. While the SA pathway is often induced by pathogen infection and piercing-sucking insects (Malamy et al. 1990, Kaloshian and Walling 2005), the JA pathway is more closely 
associated with defense against chewing herbivores (McCloud and Baldwin 1997, Walling 2000). While plants can induce both the SA and JA pathways, the two pathways are often antagonistic; the induction of one precludes expression of the other (Kunkel and Brooks 2002). This creates the possibility for defense-signaling crosstalk within plants attacked by multiple herbivores. SA pathway expression in pathogen-attacked plants, for instance, may suppress the JA pathway and increase susceptibility to subsequent herbivory. Cases where JA-SA signaling crosstalk has impacted insect performance have been documented in many plant species (Cipollini et al. 2004, Zhang et al. 2013, Schweiger et al. 2014).

The hemlock woolly adelgid (Adelges tsugae Annand; 'HWA') is a sessile herbivore native to Japan that was first recorded in the eastern United States in the 1950s (Havill et al. 2006). In the northern portion of its invaded range, this aphid-like insect feeds solely on eastern hemlock (Tsuga canadensis [L.] Carriere) by inserting its stylet into the base of a needle and feeding on xylem ray parenchyma cells (Young et al. 1995). Eastern hemlocks are highly susceptible to HWA (Montgomery et al. 2009) and trees quickly decline in health. HWA can kill even mature trees in as little as four years (McClure 1991), with some HWA-infested stands experiencing over 95\% hemlock mortality (Orwig and Foster 1998).

Although HWA poses a major threat, it is not the only insect capable of causing substantial hemlock mortality. The eastern hemlock looper (Lambdina fiscellaria Guenée; 'looper') is a native lepidopteran whose larvae defoliate hemlocks and can cause tree mortality after just four years of severe defoliation (Hudak et al. 1978). Although the looper and HWA share a host and co-occur in southern New England, very little is known 
about their interplay (Wilson et al. 2015). The potentially dramatic impacts of both herbivores on eastern hemlock forests suggests, however, that their interactions may be extremely important.

The hemlock woolly adelgid and looper differ in a number of respects. While both insects begin feeding in spring, HWA typically settle on foliage several weeks before looper larvae emerge. In addition, HWA are sessile xylem feeders while looper larvae are mobile folivores. These differences create the potential for plant-mediated interactions between HWA and the looper: previous research indicates that looper larvae may perform better on HWA-infested foliage (Wilson et al. 2015). While the mechanistic basis for these results is unknown, it may reflect herbivore-induced changes in plant defense.

Previous research has shown that HWA feeding increases the production of methyl salicylate, an ester of SA, in hemlock (Pezet and Elkinton 2014). By contrast, foliar-feeding looper larvae might be expected to increase expression of the JA pathway (Karban and Baldwin 1997, Kessler and Baldwin 2002, Van Wees et al. 2013). The cooccurrence of herbivores with different feeding modes on the same host suggests the potential for crosstalk between the SA and JA pathways. We hypothesized that looper larvae would have higher survival and perform better on foliage that had been previously infested with HWA. We also assessed whether spraying trees with chemicals designed to elicit either the JA or SA pathway would affect looper performance. We present research addressing the effects of HWA infestation on looper larval performance in the presence and absence of JA and SA pathway elicitors. In addition, an analysis of the phenolic and terpenoid content of needle tissue was performed in order to assess potential mechanisms for treatment differences in larval survival. 


\section{METHODS}

\section{Larval Survival}

In spring 2015, we purchased 300 T. canadensis saplings (0.5-0.7 m height; 'hemlocks') from Vans Pines Nursery (West Olive, MI; derived from seed collected in PA). All hemlocks were herbivore-free and had not been treated with insecticides. After potting the hemlocks, we randomly selected half of them for HWA inoculation. Trees in the HWA treatment were inoculated in June 2015 by loosely tying two HWA-infested branches to each sapling, a standard protocol (Butin et al. 2007). We collected the HWAinfested branches from trees in the Middlesex Fells Reservation (Winchester, MA), the nearest site where we could find foliage infested with only HWA. The June 2015 inoculation occurred prior to hemlock woolly adelgid emergence, allowing sistensgeneration crawlers to settle on the saplings. We held the 150 infested and 150 herbivorefree ('control') hemlocks outside the University of Rhode Island greenhouse complex (Kingston, RI), where they were watered as needed throughout summer and fall. We overwintered the trees outside, but covered them with winter protection fabric (170 grams per square yard; Griffin Greenhouse Supplies) for defense against extreme cold. We removed the winter blanket in early March 2016 and covered all of the hemlocks in insect-proof mesh (AG-15 Insect Barrier; Agribon) to prevent any early-emerging HWA crawlers from colonizing control trees.

In late March 2016, we chose thirty trees that had uniformly high HWA densities and then chose thirty uninfested trees that were similar in size to each other and to HWAinfested trees for the experiment. Ten randomly-chosen trees within each 30-tree group were assigned to one of three elicitor treatments (ethanol, salicylic acid, or jasmonic 
acid), for a total of six 10-tree treatments. We determined appropriate elicitor concentrations on the basis of published literature (Moreira et al. 2009, Sampedro et al. 2011, Moreira et al. 2012) and a series of pilot experiments. Each tree was hand-sprayed until runoff with either $40 \mathrm{mM}$ MeJA (methyl jasmonate), $20 \mu \mathrm{M}$ ASM (acibenzolar-Smethyl) (both with 2.5\% ethanol as the carrier solution), or 2.5\% ethanol, which served as the no-elicitor treatment. The spraying began in mid-May and continued weekly for four weeks. Although we had planned to apply the elicitor treatments throughout the experiment, we were forced to stop when hemlocks in the HWA + JA treatment turned brown and lost a large fraction of their needles (see Supporting Information, Fig. S1). In early May, we obtained L. fiscellaria ('looper') eggs from the Laurentian Forestry Centre of the Canadian Forest Service (Québec City, QC, Canada). Movement of the eggs from Canada to the United States, and our subsequent work with them, was covered under APHIS permit P526P-14-01875. Upon arrival at URI, all eggs were placed in a growth chamber $\left(15^{\circ} \mathrm{C}, 75 \% \mathrm{RH}, 16 \mathrm{~L} / 8 \mathrm{D}\right.$ cycle $)$ and monitored daily.

The experiment began in late May when the looper eggs began hatching. After putting a small piece of floral foam in each of 60 liter-size Ball Mason jars, we clipped a $15-\mathrm{cm}$ piece of foliage from each tree and placed it in a water-filled floral tube $(7.6 \mathrm{~cm}$ standard; Royal Imports) that we stuck into the foam. Hatchling larvae were randomly assigned to one of the 60 foliage-filled jars until each jar contained five larvae (300 total larvae). Each jar was covered with a fine white mesh ( $\sim .5 \mathrm{~mm}$; nylon) to allow ventilation but prevent escape. All 60 jars were kept in the growth chamber under the conditions described above. All jars were rotated weekly to control for potential microclimatic differences. Each jar was considered a replicate (60 total). 
We assessed looper performance by measuring larval survival, mass, and days to pupation. Eight days after the experiment began, we counted the surviving larvae in each jar and weighed them together using a Mettler Toledo scale $( \pm 0.001 \mathrm{mg})$ in order to determine average live larval mass per jar. The larvae were then returned to their respective jar in the growth chamber. We recorded survival 13 times ( weekly) throughout the experiment; larval mass was recorded on days 15, 28, 39, 49, and 62. All larvae were given fresh foliage seven days after the start of the experiment, then as often as necessary throughout the experiment. The experiment ended in late July, when the nine surviving larvae that had failed to pupate were weighed and frozen at $-20^{\circ} \mathrm{C}$ until autoclaving as per our APHIS permit.

\section{Chemical Defenses of Needle Tissue}

On June 6,2016 , three randomly-selected $\sim 10 \mathrm{~cm}$ twigs were clipped from each tree, stored in aluminum foil packets, and immediately placed in liquid nitrogen. Packets were subsequently stored at $-80^{\circ} \mathrm{C}$ until extractions were performed. For extractions, needles and twigs were separated and the two tissue types ground to powder in liquid nitrogen. Approximately $100 \mathrm{mg}$ of powdered needle tissue was placed in $1.5 \mathrm{~mL}$ microtubes, followed by the addition of $0.5 \mathrm{~mL}$ of $100 \%$ methanol. Tubes were incubated for 24 hours with occasional vortexing, after which the $9,000 \mathrm{x}$ g supernatant was removed and placed into new $1.5 \mathrm{~mL}$ tubes. The process was repeated and supernatants were eventually combined.

Total soluble phenolics were quantified according to Cipollini et al. (2011). Briefly, $20 \mu \mathrm{L}$ methanol extract was diluted with $75 \mu \mathrm{L}$ DI $\mathrm{H}_{2} \mathrm{O}$, followed by an additional $500 \mu \mathrm{L}$ DI $\mathrm{H}_{2} \mathrm{O}$. After adding $37.5 \mu \mathrm{L}$ of Folin's Phenol Reagent (Sigma), the 
tube was allowed to incubate at room temperature for 5 minutes. Afterwards, $37.5 \mu \mathrm{L} 1$ $\mathrm{M} \mathrm{NaCO}_{3}$ was added and the tube incubated at room temperature for one hour. The absorbance of $200 \mu \mathrm{L}$ aliquots in duplicate wells of Greiner UV-Star ${ }^{\circledR}$ flat-bottomed 96well microplates (Monroe, North Carolina) of the reaction solutions were quantified at 725 nm using a SpectraMAX 190 microplate reader (Molecular Devices, Sunnyvale, CA) against a standard curve of gallic acid. Soluble phenolics were expressed as $\mathrm{mg} / \mathrm{g}$ fresh weight $(\mathrm{FW})$.

For terpenoids, the spectrophotometric procedure described by Ghorai et al. (2012) was used. A $200 \mu \mathrm{L}$ aliquot of methanol extract was added to a $2 \mathrm{~mL}$ mictrotube containing $1.5 \mathrm{~mL}$ chloroform, followed by the addition of $100 \mu \mathrm{L} \mathrm{H}_{2} \mathrm{SO}_{4}$. After the samples were incubated for two hours in the dark, $1 \mathrm{~mL}$ of the top layer was removed, replaced with $1 \mathrm{~mL} 100 \%$ methanol, and the tubes were vortexed to solubilize the red precipitate. The absorbance of the solution was quantified at $538 \mathrm{~nm}$ against a standard curve of linalool, and terpenoids were expressed as mg/g FW.

\section{Statistical Methods for Analysis of Larval Survival}

All statistical analyses were performed using R Statistical Software (R Core Team 2016). Due to the unexpected decline of the HWA-infested trees sprayed with the JAelicitor, we ceased applying elicitors after four weeks, as described previously. Thus, in assessing the effects of the elicitor treatments on larval survival, we analyzed the first six data points (through Julian day 173), which coincides with the last application of the SAand JA-elicitors; larval survival after this point would not have likely been impacted by

these applications. To assess the impacts of HWA infestation of host material and elicitor applications, a repeated measures analysis of variance (rm-ANOVA) was employed. 
Survival data were arcsine-square root transformed (Lindroth et al. 1990). Percent larval survival in a given jar was the response variable and HWA infestation, elicitor application, and the interaction between the two were the predictor variables. To estimate treatment differences, individual treatment combinations were used as the predictor variable and percent survival as the response variable in a linear mixed-effect model with sampling date as the random effect. A post-hoc separation of means was then performed on this model via a Tukey test using the simultaneous tests for general linear hypotheses ('glht') function, part of the 'multcomp' package (Hothorn et al. 2008) in R.

\section{Statistical Methods for Defense Chemistry and Nutritional Attributes}

All statistics were performed using R Statistical Software (R Core Team 2016). The Shapiro-Wilk normality test was used to confirm data normality and the Dixon test was used to identify and remove outliers using the 'Outliers' package in R (Komsta 2011). An analysis of variance (ANOVA) was used to determine the significance of HWA infestation, hormone application, and the interaction between the two, with these factors as predictor variables and soluble phenolics or terpenoids as response variables. If either the interaction or hormone application predictor variables were significant, posthoc Tukey's HSD was used to determine which treatments differed from each other.

\section{RESULTS}

\section{Larval survival}

HWA infestation tended to increase larval survival over time $\left(\mathrm{F}_{1,324}=5.32\right.$, $\mathrm{P}=0.069$ ) according to the results of the repeated measures ANOVA (Table 1) (Figure 1). There was a significant negative effect of both the chemical elicitor treatment $\left(\mathrm{F}_{2,324}\right.$ $=10.30, \mathrm{P}=0.004)$ and the interaction between HWA infestation and elicitor $\left(\mathrm{F}_{2,324}=7.90\right.$, 
$\mathrm{P}=0.009$ ) on survival. The post-hoc analysis revealed that the JA treatment significantly lowered larval survival $(\mathrm{P}=0.007)$ in comparison to both the ethanol and $\mathrm{SA}$ treatments. The post-hoc analysis of the interactive effects revealed that the HWA-infested $+\mathrm{JA}(\mathrm{P}=$ $0.017)$ and the HWA-infested $+\mathrm{SA}(\mathrm{P}=0.016)$ treatments had significantly lower survival than the HWA-infested + ethanol treatment. No other treatment had a statistically significant effect on survival relative to other treatment combinations. There was also no significant effect of any treatment on larval mass (Table 1).

\section{Defense Chemistry and Nutritional Attributes}

HWA had a marginally significant effect on soluble phenolics $\left(\mathrm{F}_{1,54}=3.27, \mathrm{P}=\right.$ $0.076)$ and terpenoids $\left(\mathrm{F}_{1,54}=3.07, \mathrm{P}=0.086\right)$, while elicitor application had a significant positive effect on both phenolics $\left(\mathrm{F}_{2,54}=71.62, \mathrm{P}<0.001\right)$ and terpenoids $\left(\mathrm{F}_{2,54}=4.02, \mathrm{P}=\right.$ $0.024)$ with a nearly significant interaction effect on terpenoids $(\mathrm{F}=3.05, \mathrm{P}=0.056)$ (Table 1). For soluble phenolics, JA application significantly increased levels, regardless of HWA infestation; in contrast, SA application significantly increased levels only in the presence of HWA (Figure 2A). SA application significantly increased total terpenoids when combined with HWA infestation (Figure 2B).

\section{DISCUSSION}

Looper larvae fed HWA-infested foliage tended to have higher survival than those reared on uninfested foliage. The presence of elicitors also affected survival, and their impact was altered by HWA presence (Table 1). Looper larvae fed HWA-infested foliage treated with either the JA or SA elicitor had significantly lower survival rates than all other treatment combinations (Figure 1). We also analyzed phenolic and terpenoid content in needle tissue, both of which have been shown to negatively affect herbivorous 
insects (Feeny 1968, Bezemer et al. 2003, War et al. 2012) and play a major role in conifer resistance. The fact that both phenolic content and terpenoid levels increased with MeJA and SA application is consistent with our general understanding of the role that both metabolites play in herbivore-induced defense in hemlock.

The application of SA on uninfested foliage did not significantly increase levels of phenolics or terpenoids, and neither did HWA infestation alone. However, the combined presence of SA and HWA increased levels of both metabolites while decreasing larval survival, suggesting a causative connection between these two variables. This result may be due to defensive priming, a plant's increased readiness to induce defenses (Conrath 2009). This is often mediated by herbivore-inducible plant volatiles (HIPVs) which are frequently produced in direct response to herbivory (Kim and Felton 2012, War et al. 2012). The production of HIPVs in the attacked part of the plant can function as a signaling cue and prime defensive responses in the rest of the plant (Heil and Silva Bueno 2007, Rodriguez-Saona et al. 2009). Studies have shown plant priming can alter a variety of defensive responses, including the accumulation of secondary metabolites (Kessler et al. 2006, Hirao et al. 2012). If the initial HWA infestation defensively primed the hemlock trees, this would explain why the subsequent addition of elicitors induced greater defense, i.e., higher phenolic and terpenoid concentrations. While the potential for defensive priming is intriguing, further study is necessary to confirm that it is in fact occurring.

Our JA elicitor increased phenolic, but not terpenoid, concentrations. Applying MeJA to uninfested hemlocks increased foliar phenolics but did not alter larval survival. As a result, phenolic and terpenoid concentrations do not appear to explain low larval 
survival in the JA + HWA treatment. It is possible that JA-driven decreases in larval survival are due to factor(s) we did not quantify, such as plant nutritional quality or another defensive compound. Future research might consider analyzing factors such as carbon, nitrogen, and water content, as well as starch and tannin levels, in order to provide additional insight into interplay between plant chemistry and larval survival.

We were surprised that HWA infestation alone did not significantly alter phenolic or terpenoid levels. We did, however, find that the impact of both elicitors was only apparent when applied to HWA-infested foliage. Adelgid infestation increased survival in the absence of elicitors but decreased it in their presence: both the HWA + JA and HWA + SA treatments had significantly lower survival than the HWA + ethanol treatment. While the strong HWA by elicitor interaction is intriguing, the broad-scale chemical analyses we conducted proved insufficient to provide a clear and convincing explanation. Further hemlock tissue analyses, such as those mentioned in the previous paragraph should be done in conjunction with measures of larval survival. Additional analyses of looper larval chemistry might also improve our understanding of their physiological responses to the different treatments.

The increasing number of invasive forest pests in North America (Aukema et al. 2011) has made research addressing their direct and indirect effects increasingly important. Invasive species are estimated to cost the United States over $\$ 120$ billion annually in damages (Pimental et al. 2005). There are also significant ecological impacts of the introduction of non-native species. Invasive species are widely recognized as one of the leading causes of global species decline (Wilcove et al. 1998, NRC 2002). Studying invasive insects, for example, and their impacts on host species in their invaded 
range is certainly important, however, the resulting effects of invasion often extend beyond these immediate interactions (Kenis et al. 2009). It is increasingly important, therefore, to include potential secondary interactions and impacts when studying invasive species.

Eastern hemlock is an ecologically important forest tree and is considered a foundation species (Ellison et al. 2005). The presence and abundance of $T$. canadensis not only defines a hemlock forest, but greatly influences both terrestrial and aquatic habitats (Snyder et al. 2002, Tingley et al. 2002). It is currently experiencing widespread mortality due to the invasive hemlock woolly adelgid (Orwig and Foster 1998). The eastern hemlock looper, another hemlock pest, is a native lepidopteran that has reached outbreak levels in the past (Hudak et al. 1978). Little is known about the relationship between these insects, such as how feeding by both may affect the chemical profile of their host, and how this plant-mediated interaction affects each species. While HWA infestation poses a significant threat to North America's hemlock forests, it is not an isolated system: the overlap of hemlock looper and HWA presents an opportunity to study interactions between a native herbivore and an invasive pest. Our results provide insight into the interactions occurring between two ecologically-important insect herbivores and their shared host plant. Further study may reveal additional insights applicable to other systems where native and invasive insect species interact.

\section{Acknowledgements}

We thank E. Shoemaker, N. Houseman, A. Baranowski, and L. Tewksbury for their laboratory assistance. We also thank G. Puggioni for his assistance with data analysis. This project was funded by National Science Foundation grants NSF-DEB 1256826 to C. 
Orians and NSF-DEB 1256769 to E. Preisser and C. Thornber. Any opinions, findings, and conclusions or recommendations expressed in this material are those of the authors and do not necessarily reflect the views of the National Science Foundation. 


\section{LITERATURE CITED}

Agrawal, A. A. 1999. Induced responses to herbivory in wild radish: effects on several herbivores and plant fitness. Ecology 80:1713-1723.

Aukema, J. E., B. Leung, K. Kovacs, C. Chivers, K. O. Britton, J. Englin, S. J. Frankel, R. G. Haight, T. P. Holmes, A. M. Liebhold, D. G. McCullough, and B. Von Holle. 2011. Economic impacts of non-native forest insects in the continental United States. PLoS One 6:e24587.

Bezemer, T. M., R. Wagenaar, N. M. Van Dam, and F. L. Wäckers. 2003. Interactions between above- and belowground insect herbivores as mediated by the plant defense system. Oikos 101:555-562.

Butin, E., E. Preisser, and J. Elkinton. 2007. Factors affecting settlement rate of the hemlock woolly adelgid, Adelges tsugae, on eastern hemlock, Tsuga canadensis. Agricultural and Forest Entomology 9:215-219.

Cipollini, D., S. Enright, M. B. Traw, and J. Bergelson. 2004. Salicylic acid inhibits jasmonic acid-induced resistance of Arabidopsis thaliana to Spodoptera exigua. Molecular Ecology 13:1643-1653.

Cipollini, D., Q. Wang, J. G. A. Whitehill, J. R. Powell, P. Bonello, and D. A. Herms. 2011. Distinguishing defensive characteristics in the phloem of ash species resistant and susceptible to emerald ash borer. Journal of Chemical Ecology 37:450-459.

Denno, R. F., M. S. McClure, and J. R. Ott. 1995. Interspecific interactions in phytophagous insects: competition reexamined and resurrected. Annual Review of Entomology 40:297-331. 
Faeth, S. H. 1986. Indirect interactions between temporally separated herbivores mediated by the host plant. Ecology 67:479-494.

Feeny, P. P. 1968. Effect of oak leaf tannins on larval growth of the winter moth Operophtera brumata. Journal of Insect Physiology 14:805-817.

Ghorai, N., S. Chakraborty, S. Gucchait, S. K. Saha, and S. Biswas. 2012. Estimation of total terpenoids concentration in plant tissues using a monoterpene, Linalool as standard reagent. Nature: Protocol Exchange.

Harrison, S., and R. Karban. 1986. Effects of an early-season folivorous moth on the success of a later-season species, mediated by a change in the quality of the shared host, Lupinus arboreus Sims. Oecologia 69:354-359.

Havill, N., M. Montgomery, G. Yu, S. Shiyake, and A. Caccone. 2006. Mitochondrial DNA from hemlock woolly adelgid (Hemiptera: Adelgidae) suggests cryptic speciation and pinpoints the source of the introduction to eastern North America. Annals of the Entomological Society of America 99:195-203.

Hothorn, T., F. Bretz, and P. Westfall. 2008. Simultaneous inference in general parametric models. Biometrical Journal 50:346-363.

Hudak, J., G. Laflamme, and J. P. Meades. 1978. Deterioration of baslam fir damaged by the eastern hemlock looper in Newfoundland. Canadian Forest Service, Newfoundland Forest Research Center N-X-157.

Kaloshian, I., and L. L. Walling. 2005. Hemipterans as plant pathogens. Annual Review of Phytopathology 43:491-521.

Karban, R., and I. T. Baldwin. 1997. Induced responses to herbivory. The University of Chicago Press, Chicago. 
Kessler, A., and I. T. Baldwin. 2002. Plant responses to insect herbivory: the emerging molecular analysis. Annual Review of Plant Biology 53:299-328.

Komsta, L. 2011. Outliers: Tests for outliers. R package version 0.14 .

Kunkel, B. N., and D. M. Brooks. 2002. Cross talk between signaling pathways in pathogen defense. Current Opinion in Plant Biology 5:325-331.

Leitner, M., W. Boland, and A. Mithöfer. 2005. Direct and indirect defences induced by piercing-sucking and chewing herbivores in Medicago truncatula. New Phytologist 167:597-606.

Lindroth, R. L., B. D. Anson, and A. V. Weisbrod. 1990. Effects of protein and juglone on gypsy moths: growth performance and detoxification enzyme activity. Journal of Chemical Ecology 16:2533-2547.

Malamy, J., J. P. Carr, D. F. Klessig, and I. Raskin. 1990. Salicylic acid: a likely endogenous signal in the resistance response of tobacco to viral infection. Science 250:1002-1004.

Mattson, W. J. 1986. Competition for food between two principal cone insects of red pine, Pinus resinosa. Environmental Entomology 15:88-92.

McCloud, E. S., and I. T. Baldwin. 1997. Herbivory and caterpillar regurgitants amplify the wound-induced increases in jasmonic acid but not nicotine in Nicotiana sylvestris. Planta 203:430-435.

McClure, M. 1991. Density-dependent feedback and population cycles in Adelges tsugae (Homoptera: Adelgidae) on Tsuga canadensis. Environmental Entomology 20:258-264. 
Montgomery, M. E., S. E. Bentz, and R. T. Olsen. 2009. Evaluation of hemlock (Tsuga) species and hybrids for resistance to Adelges tsugae (Hemiptera: Adelgidae) using artificial infestation. Journal of Economic Entomology 102:1247-1254.

Moreira, X., L. Sampedro, and R. Zas. 2009. Defensive responses of Pinus pinaster seedlings to exogenous application of methyl jasmonate: concentration effect and systemic response. Environmental and Experimental Botany 67:94-100.

Moreira, X., R. Zas, and L. Sampedro. 2012. Quantitative comparison of chemical, biological, and mechanical induction of secondary compounds in Pinus pinaster seedlings. Trees 26:677-683.

Nurmi, K., V. Ossipov, E. Haukioja, and K. Pihlaja. 1996. Variation of total phenolic content and individual low-molecular-weight phenolics in foliage of mountain birch trees (Betula pubescens ssp. tortuosa). Journal of Chemical Ecology 22:2023-2040.

Orwig, D. A., and D. R. Foster. 1998. Forest response to the introduced hemlock woolly adelgid in southern New England, USA. Journal of the Torrey Botanical Society 125:60-73.

Park, T. 1948. Interspecies competition in populations of Trilobium confusum Duval and Trilobium castaneum Herbst. Ecological Monographs 18:265-307.

Pezet, J., and J. S. Elkinton. 2014. Hemlock woolly adelgid (Hemiptera: Adelgidae) induces twig volatiles of eastern hemlock in a forest setting. Environmental Entomology 43:1275-1285.

Rodriguez-Saona, C. R., R. O. Musser, H. Vogel, S. M. Hum-Musser, and J. S. Thaler. 2010. Molecular, biochemical, and organismal analyses of tomato plants 
simultaneously attacked by herbivores from two feeding guilds. Journal of Chemical Ecology 36:1043-1057.

Sampedro, L., X. Moreira, and R. Zas. 2011. Resistance and response of Pinus pinaster seedlings to Hylobius abietis after induction with methyl jasmonate. Plant Ecology 212:397-401.

Schweiger, R., A. M. Heise, M. Persicke, and C. Muller. 2014. Interactions between the jasmonic and salicylic acid pathway modulate the plant metabolome and affect herbivores of different feeding types. Plant, Cell \& Environment 37:1574-1585.

Soler, R., F. R. Badenes-Pérez, C. Broekgaarden, S.-J. Zheng, A. David, W. Boland, and M. Dicke. 2012. Plant-mediated facilitation between a leaf-feeding and a phloemfeeding insect in a brassicaceous plant: from insect performance to gene transcription. Functional Ecology 26:156-166.

Van Wees, S. C., J. A. Van Pelt, P. A. Bakker, and C. M. Pieterse. 2013. Bioassays for assessing jasmonate-dependent defenses triggered by pathogens, herbivorous insects, or beneficial rhizobacteria. Methods in Molecular Biology 1011:35-49.

Walling, L. L. 2000. The myriad plant responses to herbivory. Journal of Plant Growth Regulation 19:195-216.

War, A. R., M. G. Paulraj, T. Ahmad, A. A. Buhroo, B. Hussain, S. Ignacimuthu, and H. C. Sharma. 2012. Mechanisms of plant defense against herbivores. Plant Signaling \& Behavior 7:1306-1320.

War, A. R., M. G. Paulraj, M. Y. War, and S. Ignacimuthu. 2011. Role of salicylic acid in induction of plant defense system in chickpea (Cicer arietinum L.). Plant Signaling \& Behavior 6:1787-1792. 
Wilson, C. M., J. F. Vendettuoli, D. A. Orwig, and E. L. Preisser. 2015. Impact of an invasive insect and plant defense on a native forest defoliator. Insects 7:45.

Young, R., K. Shields, and G. Berlyn. 1995. Hemlock woolly adelgid (Homoptera:

Adelgidae): stylet bundle insertion and feeding site. Annals of the Entomological Society of America 88:827-835.

Zhang, P.-J., W.-D. Li, F. Huang, J.-M. Zhang, F.-C. Xu, and Y.-B. Lu. 2013. Feeding by whiteflies suppresses downstream jasmonic acid signaling by eliciting salicylic acid signaling. Journal of Chemical Ecology 39:612-619. 


\section{Tables}

Table 1: Statistical analysis of the impact of HWA, elicitors, and their interactions on measured response variables.

\begin{tabular}{|l|c|c|c|c|}
\hline Response & Factor & F-value & df & P-value \\
\hline Larval Survival & HWA & 5.32 & 1,324 & 0.069 \\
\cline { 2 - 5 } & Elicitor & 10.30 & 2,324 & $0.004^{*}$ \\
\cline { 2 - 5 } & HWA x Elicitor & 7.90 & 2,324 & $0.009^{*}$ \\
\hline \multirow{4}{*}{ Larval Mass } & HWA & 2.13 & 1,77 & 0.148 \\
\cline { 2 - 5 } & Elicitor & 0.98 & 2,77 & 0.380 \\
\cline { 2 - 5 } & HWA x Elicitor & 0.63 & 2,77 & 0.534 \\
\hline Soluble Phenolics & HWA & 3.27 & 1,54 & 0.076 \\
\cline { 2 - 5 } & Elicitor & 71.62 & 2,54 & $<0.001^{*}$ \\
\cline { 2 - 5 } & HWA x Elicitor & 27.42 & 2,54 & $<0.001^{*}$ \\
\hline Terpenoids & HWA & 3.07 & 1,54 & 0.086 \\
\cline { 2 - 5 } & Elicitor & 4.02 & 2,54 & $0.024^{*}$ \\
\cline { 2 - 5 } & HWA x Elicitor & 3.05 & 2,54 & 0.056 \\
\hline
\end{tabular}

$*_{\text {statistical significance }(}(\mathrm{P}<0.05)$ 


\section{Figure Legends}

Figure 1: Percent looper larval survival over time. Dotted lines correspond to HWAinfested treatments; solid lines correspond to uninfested. Color denotes the chemical treatment (blue $=$ ethanol, purple $=\mathrm{JA}$, green $=\mathrm{SA}$ ).

Figure 2: Defense chemistry of sampled needle tissue. Bars (mean $\pm \mathrm{SEM}$ ) with same letter(s) are not significantly different by Tukey’s test $(\mathrm{P} \leq 0.05)$. A: Soluble phenolics (mg/g FW) of needle tissue sampled from each treatment. The application of JA significantly increased phenolics in both HWA-infested and uninfested treatments. The application of SA increased phenolics only in combination with HWA infestation. B: Terpenoids (mg/g FW) in needle tissue sampled from each treatment. The application of SA when combined with HWA infestation significantly increased total terpenoids. 
Figure 1

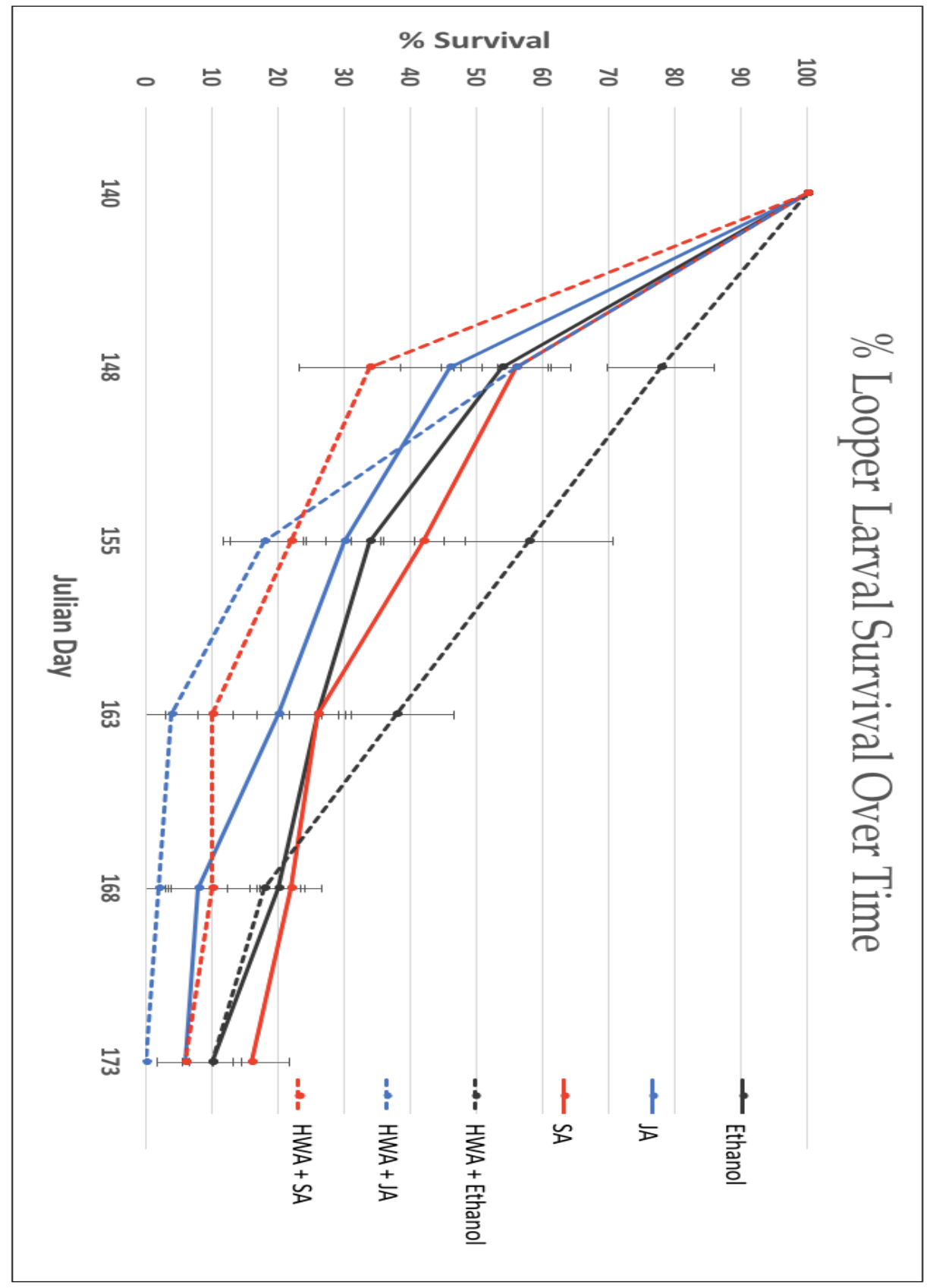


Figure 2

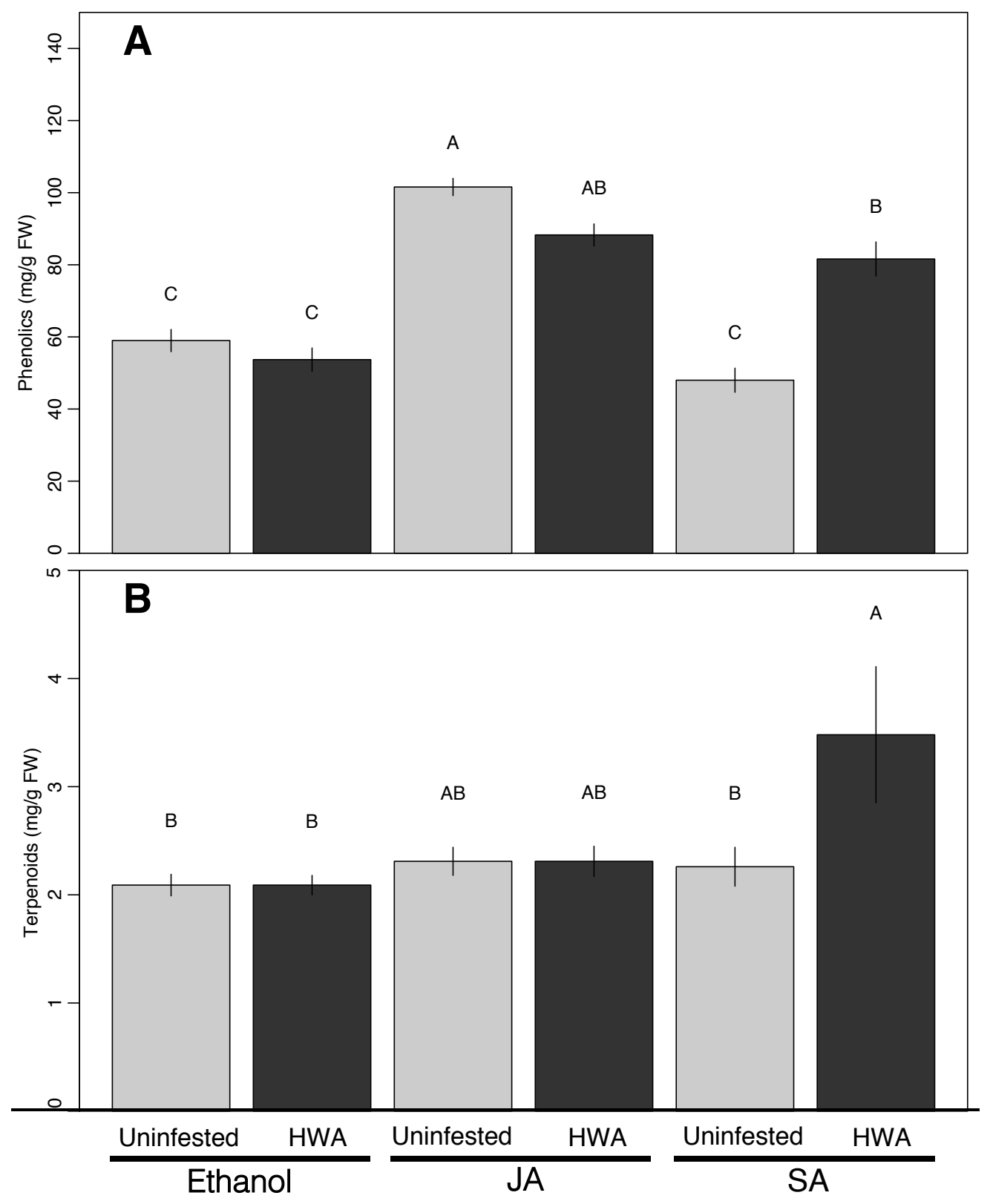




\section{Supporting Information}

Figure S1: Images of representative trees from each treatment group. Trees in the HWA+JA group (highlighted in yellow) suffered dramatic needle loss and were visibly more stressed than trees from all other treatment groups.

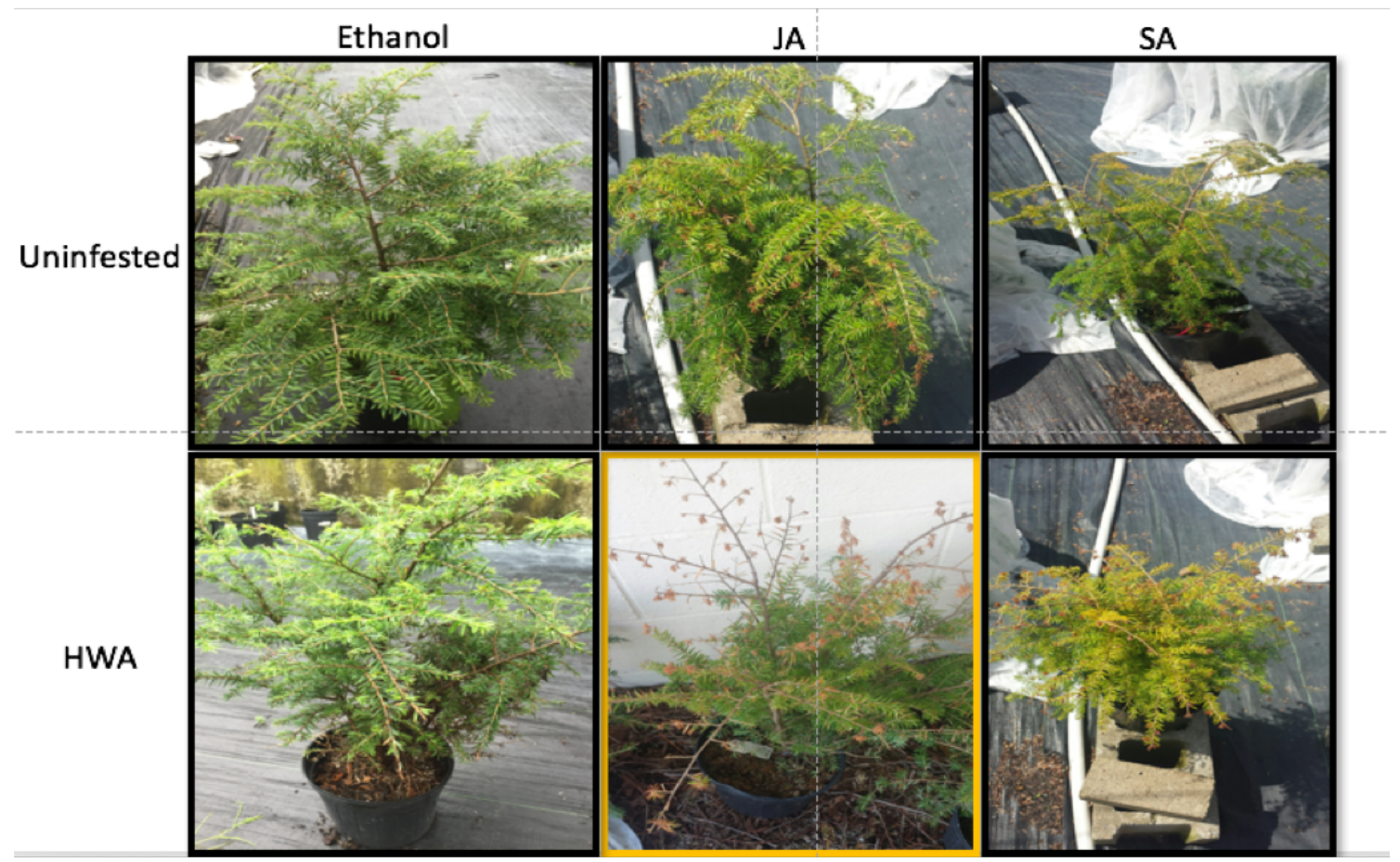

